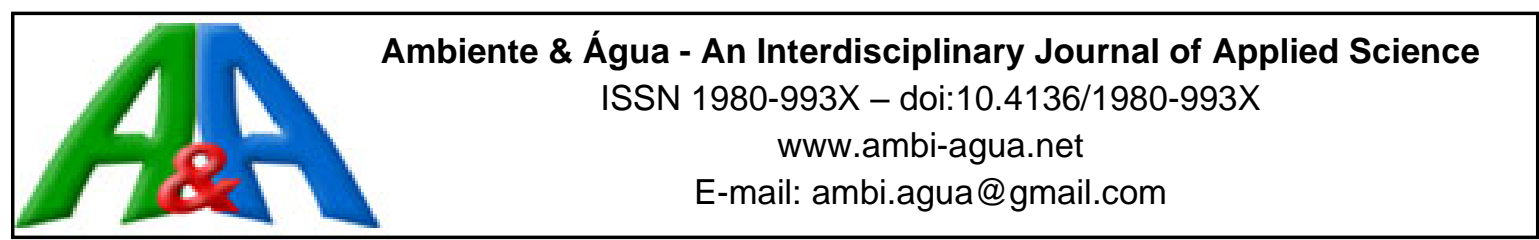

\title{
The growing international relevance of Ambiente \& Água according to Scopus CiteScore results
}

EDITORIAL doi:10.4136/ambi-agua.2670

Received: 18 Jun. 2021; Accepted: 29 Jun. 2021

Nelson Wellausen Dias

Instituto de Pesquisas Ambientais em Bacias Hidrográficas (IPABHi), Estrada Municipal

Doutor José Luiz Cembranelli, n 5.000, CEP: 12081-010, Taubaté, SP, Brazil.

E-mail: nwdias@gmail.com

\begin{abstract}
The Ambiente \& Água Journal has adopted strategies in recent years to increase its relevance within the international scientific community. The results of CiteScore, recently released for the triennium ending in 2020, indicate that the journal's strategies are starting to show good results. Evidence of an increase in the proportion between the number of citations received versus the number of documents published is corroborated by the impact indicators from other sources, such as the Scimago Journal Rank (SJR) and Leiden University's Centre for Science and Technology Studies (CWTS) Impact per Publication (IPP). Also positive is the fact that the journal's impact is increasing even with the increase in the number of papers published, contrary to the strategy adopted by some journals that limit the number of papers in order to increase the journal's impact.
\end{abstract}

Keywords: foreign citations, impact factor, internationalization.

\section{O aumento da relevância internacional da Ambiente \& Água conforme os resultados do Scopus CiteScore}

\section{RESUMO}

A Revista Ambiente \& Água tem adotado estratégias para aumentar sua relevância dentro da comunidade científica internacional nos últimos anos. Os resultados do CiteScore, recentemente divulgados para o triênio terminado em 2020, indicam que as estratégias da revista começam a mostrar bons resultados. Corroboram com as evidências de aumento da proporção entre o número de citações recebidas versus o número de documentos publicados os indicadores de impacto de outras fontes, como o SJR e o IPP do CWTS. Também é positivo o fato de que o impacto da revista está aumentando mesmo com o aumento no número de artigos publicados, ao contrário da estratégia adotada por alguns periódicos que limitam o número de artigos para aumentar o impacto da revista.

Palavras-chave: citações estrangeiras, fator de impacto, internacionalização.

\section{AMBIENTE \& ÁGUA INTERNATIONALIZATION BACKGROUND}

The year 2013 as described by Batista (2013) was "a year not to be forgotten". In that year, the Ambiente \& Agua journal was approved to integrate with the Scopus collection, and was 
later accepted to be part of the Scientific Electronic Library Online (SciELO). Finally, in the same year, it received a grant from CAPES (a Brazilian scientific funding agency) to encourage editing and publication of Brazilian research papers. Therefore, 2013 was the starting point of Ambiente \& Água's internationalization process, even though this was perceived by its members as an outstanding challenge due to the commitments made to keep our memberships with Scopus and SciELO over time.

Now, just eight years later, the journal has begun to benefit from that challenge. In the meantime, other decisions were crucial to achieving the current positive results, such as the decision to publish only in English and to adopt a continuous publication mode, both implemented in 2018. Also, the decision to utilize Clarivate's reviewer selection tool and Publons reviewer recognition tool added positive impacts to the process. The adoption of these tools was a key ingredient to improve the journal's international relevance by expanding the number of foreign reviewers who also came to know the journal and, as a consequence, began to cite papers published by Ambiente \& Água.

The two main pieces of evidence of this international relevance expansion are the increase in the H-index score and Scopus CiteScore. In this editorial, the focus is on CiteScore results with additional comparison to other metrics, such as SJR and IPP.

\section{HOW CITESCORE WORKS}

The CiteScore method was described by James et al. (2019) as follows, based on an example of the 2017 calculation (Figure 1):

"Citations (A) is the sum of citations in 2017 (i.e., where the citing publication year is 2017) that are linked to publications in a journal with a (cited) publication year of 2014, 2015 or 2016. Documents (B) is the count of all publications in a journal with a publication year of 2014, 2015 or 2016, excluding articles-in-press. CiteScore is calculated by dividing the Citations (A) by Documents (B). CiteScore is calculated to two decimal places" (James et al., 2019).

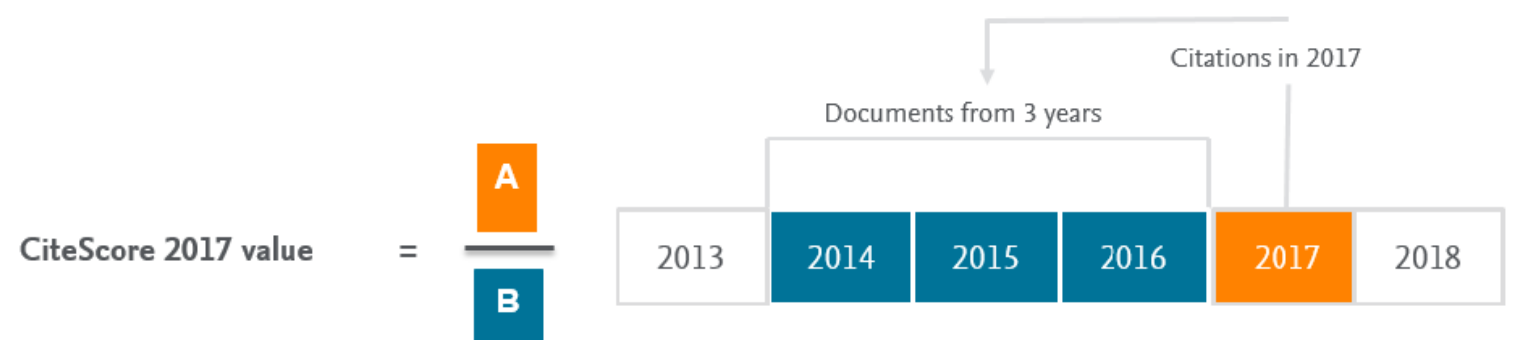

Figure 1. CiteScore calculation method based on a 2017 example. Source: James et al. (2019).

CiteScore metrics were developed taking into account three desirable characteristics of journal citation metrics, as pointed out by James et al. (2019): (1) be transparent, (2) be comprehensive, and (3) be current. According to the same authors, CiteScore metrics complement the more sophisticated metrics, SNIP and SJR, that are also calculated based on Scopus data of over 22,000 serial titles. In order to evaluate the impact factor of a journal, it is recommended that not only one metric be used, but a comparison of two or more.

\section{AMBIENTE \& ÁGUA CITESCORE RESULTS FROM 2015 TO 2020}

Ambiente \& Água was integrated into Scopus in 2013, therefore the CiteScore results (SCOPUS, 2021) presented on Figure 2 take into account the number of citations and published 
documents in the previous three years, starting in 2015, which considered data between 2012 and 2014. After Ambiente \& Água was integrated into the SciELO collection, our goal was to publish at least 80 manuscripts per year, a goal clearly observed by the total number of documents after 2016. Between 2015 and 2017 our journal still published papers in three languages (Portuguese, English and Spanish) and from 2018 it was decided to publish only in English. The CiteScore increase between 2015 and 2017 was due to the increasing recognition of Ambiente \& Água as a relevant journal in the field of Environmental Science, mostly among the Brazilian scientific community. The new increasing trend initiated in 2018 is believed to be associated with the growing relevance of Ambiente \& Água among the international scientific community, but still with a considerable influence within the Brazilian community. The fact that the number of citations received surpassed the number of documents published in the recently released 2020 CiteScore result is an achievement to be celebrated by Ambiente \& Água.

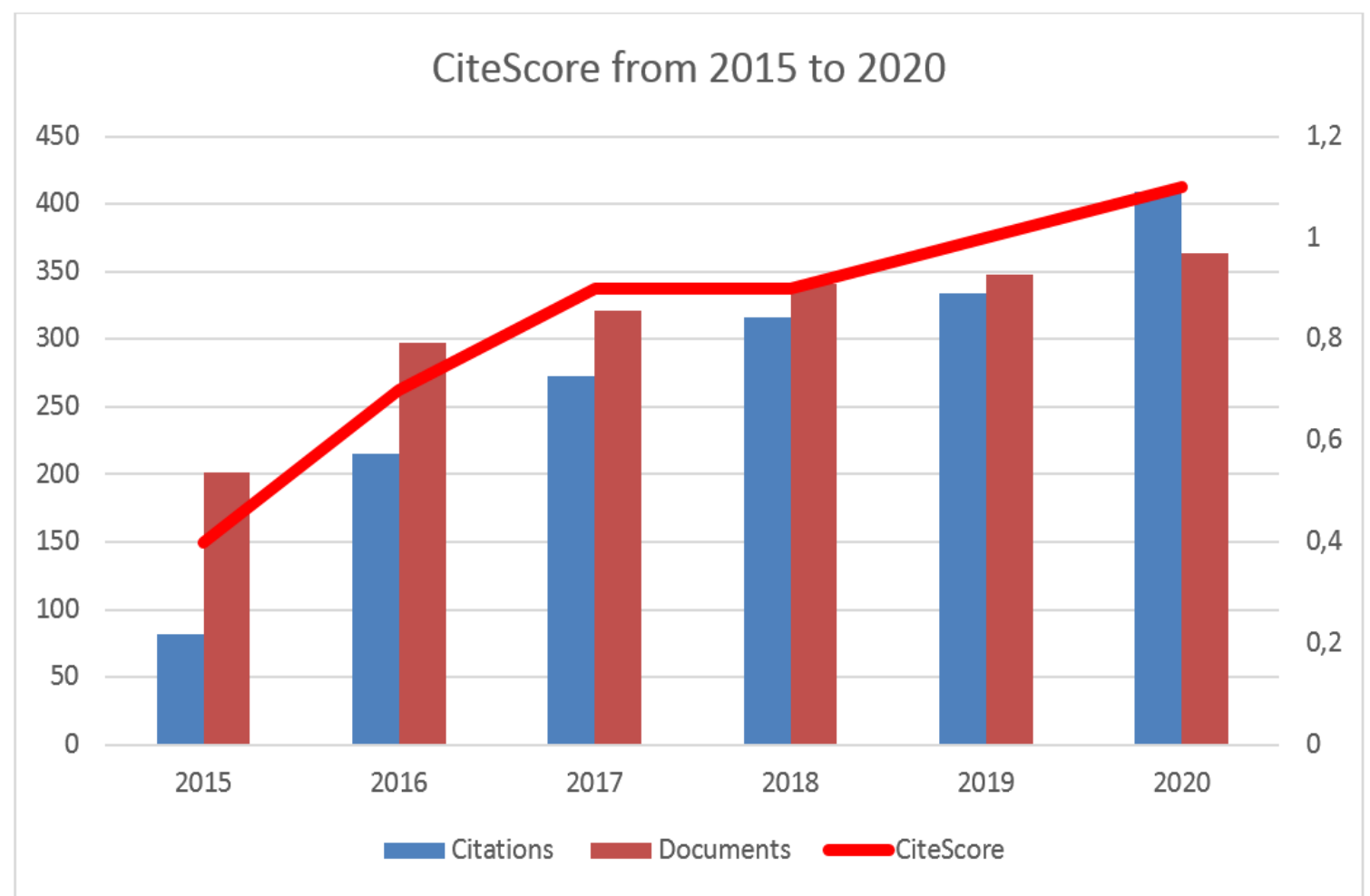

Figure 2. Compilation of the number of citations received, the number of documents published, and the CiteScore results between 2015 and 2020.

\section{THE INCREASING DIVERSE CITATION SCOPE OF AMBIENTE \& ÁGUA}

In order to analyze the scope of citations received in the 2020 CiteScore result, a list of all citations received was downloaded and reviewed. Figure 3 presents the results based on the following analysis criteria: all citations were classified in Foreign Citations, that is, citations received from non-Brazilian authors and journals; and Self-citations, that is, citations received from Ambiente \& Água Journal published documents.

In total, Ambiente \& Água received 334 citations in the three-year period between 2018 and 2020. Foreign citations totalled 105 , which corresponds to $31.4 \%$ of all citations. This the first time that such analysis was conducted by our journal's board and the results are extremely significant, since most of our audience, up to a few years ago, was composed of Brazilian scientific community members. Also significant is the number of Self-citations received, a total 
of 59 that corresponds to $17.6 \%$, a percentage that has decreased in recent years. The relevant number of foreign citations is believed to be associated to three main factors: the decision to publish all papers in English, the adoption of a reviewer selection tool provided by Clarivate Analytics in the ScholarOne Manuscripts tool, and the implementation of Publons reviewer recognition tool. The combination of these factors is believed to be crucial to the recognition of Ambiente \& Água as an important scientific journal by the international scientific community.

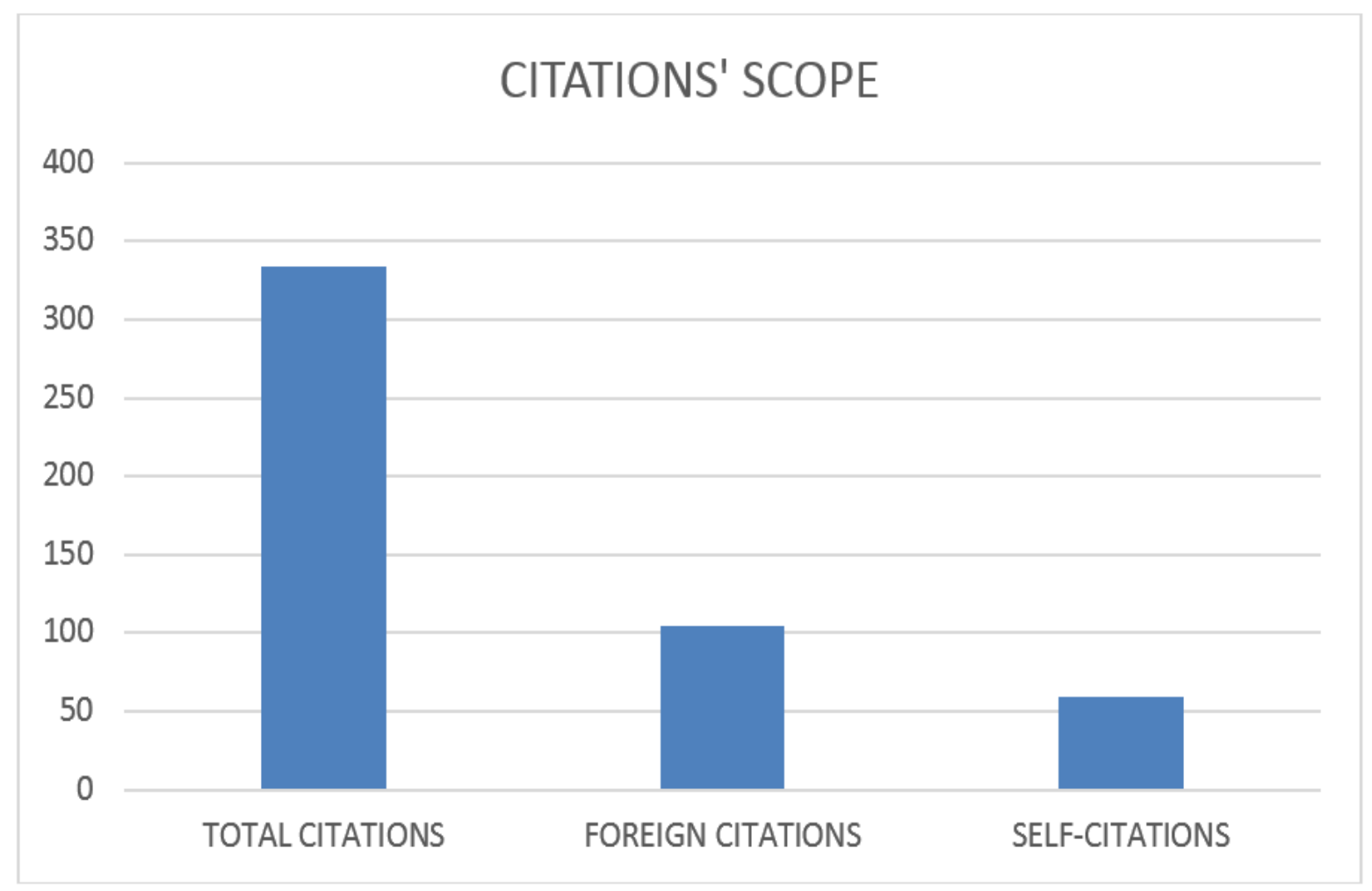

Figure 3. Result of citation scope analysis from CiteScore 2020 downloaded data.

\section{ADDITIONAL EVIDENCE FROM OTHER METRICS}

As mentioned earlier, it is recommended that a journal's impact should be evaluated based on more than one metric. This is why results from Scimago Journal Rank (SJR, 2021) and Leiden University's Centre for Science and Technology Studies (CWTS) Impact per Publication (IPP) metrics (CWTS, 2021) are presented in Figure 4.

In the top left graphic of Figure 4, the number of cited over uncited documents has increased between 2018 and 2020, which could explain part of the general increase in the number of citations received shown in Figure 2. The graphic immediately below provides insights into the increasing difference between total cites and self-cites, which also reinforce the percentage reduction of self-citation presented in Figure 3. The top right graphic in Figure 4 shows three ratios of cites per document based on two-, three- and four-year periods. Even though the shape of these three lines is similar to the CiteScore line in Figure 2, the SJR increase between 2019 and 2020 is more dramatic, varying from 0.65 to 1.0, while CiteScore varies from 0.9 to 1.1. This difference reinforces the need to use more than one metric to evaluate a journal's impact performance over time. Finally, the bottom graphic of Figure 4 shows the CWTS' IPP variation between 2014 and 2020. In this graphic, a similar plateau is observed between 2016 and 2019, but a clear increase can also be observed between 2019 and 2020, as observed in both SJR and CiteScore results. 
Cited documents Uncited documents

$\curvearrowleft$ Citations per document
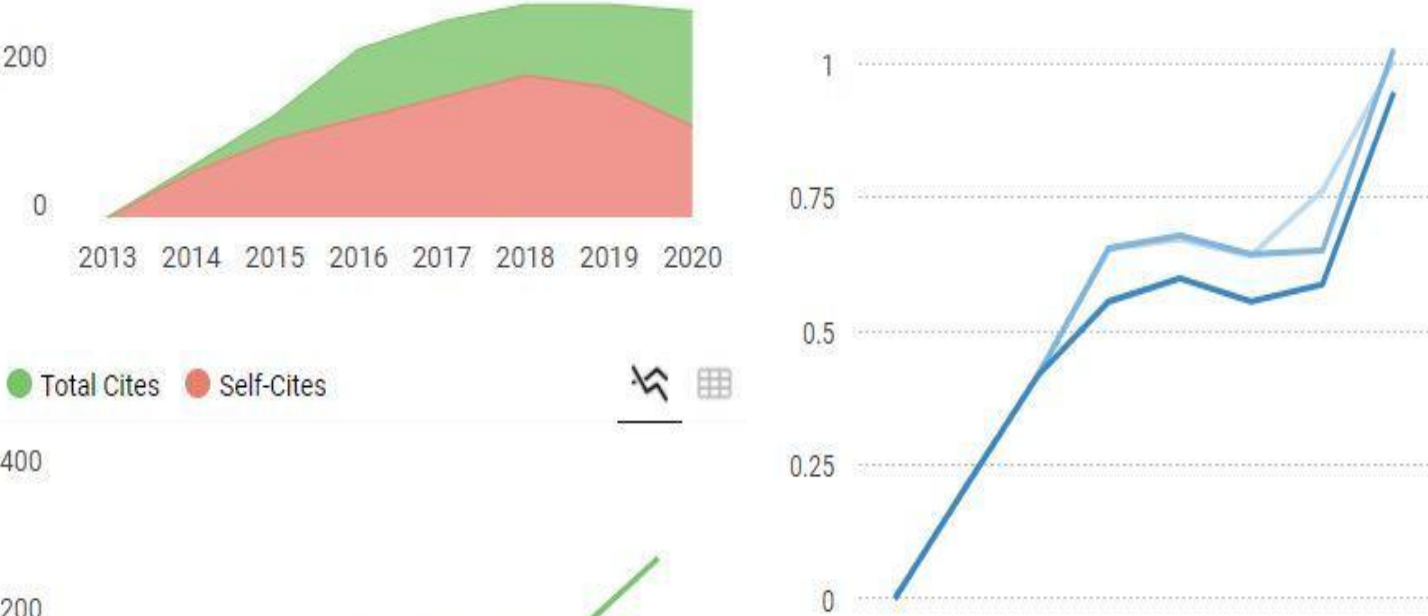

200

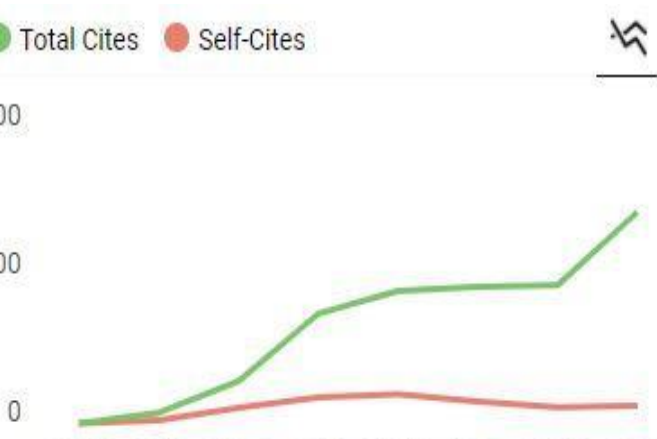

$201320142015 \quad 20162017201820192020$
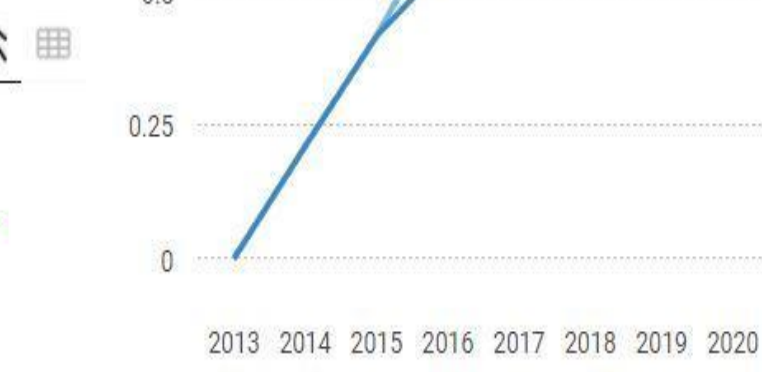

Cites / Doc. (4 years)

Cites / Doc. (3 years)

Cites / Doc. (2 years)

\section{Revista Ambiente e Agua}

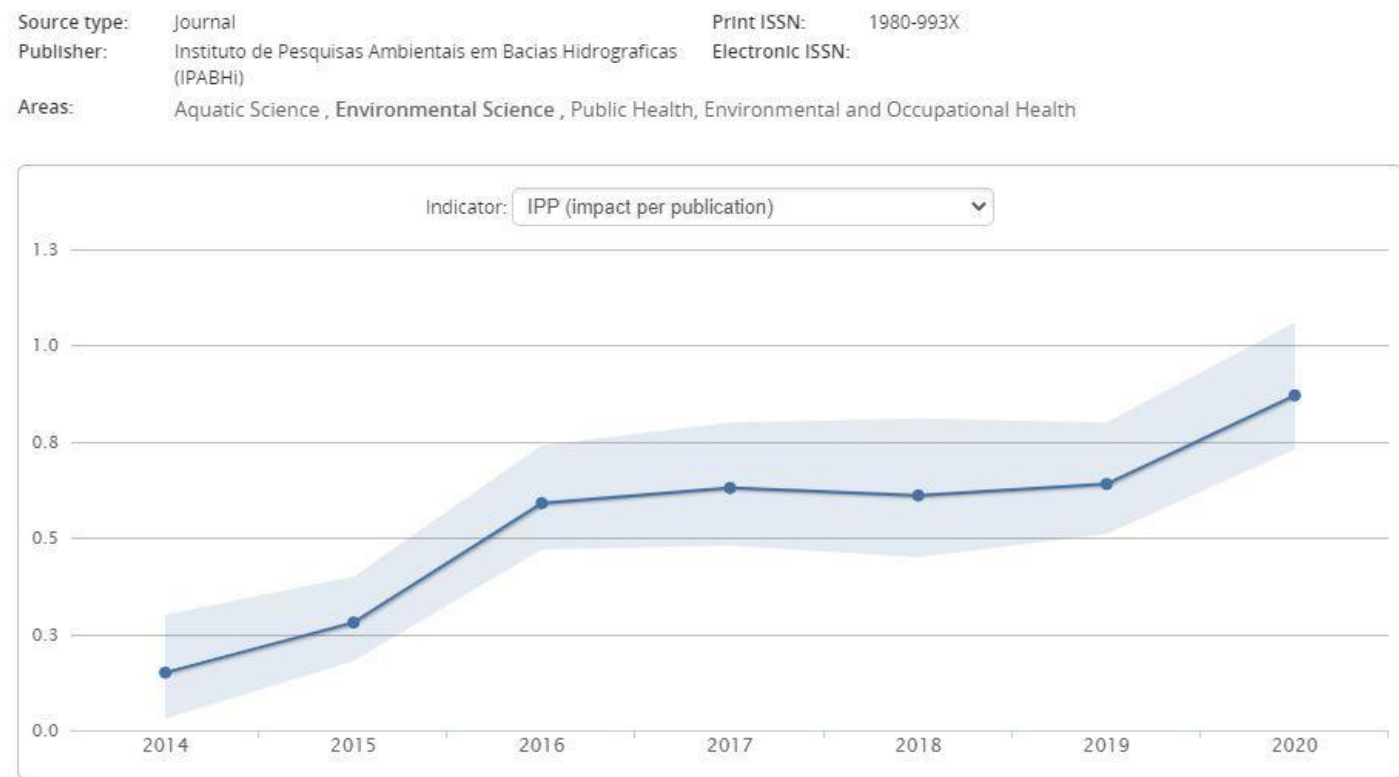

Figure 4. Additional metrics provided by Scimago's SJR and CWTS's IPP.

\section{FINAL REMARKS}

Even though differences occur in the specific metrics of individual results when compared year by year, a clear trend is evident when observing CiteScore with SJR and IPP in the entire range between 2015 and 2020. More specifically, there is a growing trend before 2017, followed by a plateau between 2017 and 2019 and an initial stage of a new growing trend after 2019 . 
These trends are in line with the decisions made by the journal board with the objective of increasing its international relevance among the scientific community.

Some scientific journals implement strategies to severely limit the number of papers published per year in order to improve their citation/document ratio and take the advantage of inflating their CiteScore. Revista Ambiente \& Água has chosen to publish every manuscript that deserves to be published based on the quality of the research presented and the opinion of our peer review board. Even though this strategy may increase the risk of damaging our journal's CiteScore, that decision remains and has benefited many researchers who had their research results published by Revista Ambiente \& Água.

\section{REFERENCES}

BATISTA, G. T. Editorial of the twenty third edition of Ambiente \& Água Journal. Revista Ambiente \& Água, v. 8, n. 3, 2013. https://doi.10.4136/ambi-agua.1258

CWTS. Journal Indicators - IPP for Revista Ambiente e Água. Available at: https://www.journalindicators.com/indicators/journal/21100239409 Access: July 2021.

JAMES, C.; COLLEDGE, L.; MEESTER, W.; AZOULAY, N.; PLUME, A. CiteScore metrics: Creating journal metrics from the Scopus citation index. Learned Publishing, v. 32, n. 4, p. 367-374, 2019. https://doi./10.1002/leap.1246

SCOPUS. Source Details for Revista Ambiente e Água. Available at: https://www.scopus.com/sourceid/21100239409 Access: July 2021.

SJR. Scimago Journal \& Country Rank for Revista Ambiente e Água. Available at: https://www.scimagojr.com/journalsearch.php?q=21100239409\&tip=sid\&clean=0 Access: July 2021. 